\title{
TRADE REMEDIES AND WORLD TRADE ORGANIZATION DISPUTE SETTLEMENT: WHY ARE SO FEW CHALLENGED?
}

\author{
Chad P. Bown ${ }^{\dagger, *}$ \\ The Brookings Institution \\ \& Brandeis University
}

\begin{abstract}
Antidumping and related trade remedies are the most popular policy instruments that many of the largest importing countries in the World Trade Organization system use to restrict international trade. While such trade remedies are also frequent targets of dispute settlement activity under the WTO, given that Panel and Appellate Body rulings have almost invariably found that some aspect of each reviewed remedy was inconsistent with WTO obligations, an open research question is why aren't more remedies targeted by dispute settlement? This paper provides a first empirical investigation of the trade remedy and WTO dispute settlement interaction by focusing on determinants of WTO members' decisions of whether to formally challenge U.S. trade remedies imposed between 1992 and 2003. We provide evidence that it is not only the size of the economic market at stake and the capacity to retaliate under potential Dispute Settlement Understanding-authorized sanctions that influence the litigation decision of whether to formally challenge a measure at the WTO. We also find that if the negatively affected foreign industry has the capacity to directly retaliate through a reciprocal antidumping investigation and measure of its own, its government is less likely to pursue the case on its behalf at the WTO. This is consistent with the theory that potential complainants may be avoiding WTO litigation in favor of pursuing reciprocal antidumping and hence "vigilante justice."
\end{abstract}

JEL No. F13, K33, K41

Keywords: Trade Disputes, WTO, GATT, Antidumping, Countervailing Duties, Trade Remedies, Retaliation

World Bank Policy Research Working Paper 3540, March 2005

The Policy Research Working Paper Series disseminates the findings of work in progress to encourage the exchange of ideas about development issues. An objective of the series is to get the findings out quickly, even if the presentations are less than fully polished. The papers carry the names of the authors and should be cited accordingly. The findings, interpretations, and conclusions expressed in this paper are entirely those of the authors. They do not necessarily represent the view of the World Bank, its Executive Directors, or the countries they represent. Policy Research Working Papers are available online at http://econ.worldbank.org.

\footnotetext{
$\dagger$ Okun-Model Fellow in Economic Studies (The Brookings Institution) and Department of Economics and International Business School (Brandeis University).

Correspondence: The Brookings Institution, 1775 Massachusetts Avenue, NW, Washington, DC 20036 USA tel: 202-797-6304, fax: 202-797-2478, email: cbown@brookings.edu, web: http://www.brandeis.edu/ cbown/.

* For helpful discussions and comments on an earlier version of this paper, I would like to thank Alan Sykes, Eric Posner, Tom Prusa, Robert Staiger, Kyle Bagwell, Michael Moore, Nuno Limão, Marc Busch, Susan Collins, Barry Bosworth and seminar participants at the Conference on International Dispute Resolution (University of Chicago Law School), The Brookings Institution, George Washington University and the U.S. International Trade Commission. A portion of this research was undertaken while I was visiting the Trade Unit in the Development Economics Research Group at the World Bank, which I thank for its financial support. Gloria Sheu and Eric Haven provided outstanding research assistance.
} 


\section{$1 \quad$ Introduction}

Antidumping and other national trade remedy laws such as countervailing duties and safeguards occupy an uneasy position in the GATT/WTO system. National governments have been explicitly authorized under various GATT and WTO Agreements to implement such laws and to set up procedures through which domestic industries and/or workers initiate petitions and use the trade remedy laws' provisions to limit competition from injurious imports. Nevertheless, though trade remedies are, in principle, consistent with a member's WTO obligations, negatively affected trading partners routinely request that formal dispute settlement panels be established to examine the WTO-consistency of their use. Table 1 illustrates how, by one measure - simply counting the requests for consultations received under the WTO's Dispute Settlement Understanding (DSU) - disputes relating to trade remedies made up nearly one-half of all WTO disputes initiated between 1999 and 2004. This is a clear shift in litigation emphasis from the period immediately following the WTO's inception, when less than one in seven disputes concerned trade remedies. ${ }^{1}$

That such a large share of the WTO dispute settlement caseload involves challenges to antidumping, countervailing duties and safeguards is perhaps not surprising, given the relative transparency of these policies and the cross-country proliferation of antidumping use in particular. Zanardi (2004), for example, reports that countries imposed over 1,000 antidumping measures after over 1,600 investigations between 1995 and 2001 alone. $^{2}$ Furthermore, WTO dispute panels have held and the Appellate Body has confirmed WTO-inconsistencies with at least one element of almost every trade remedy action that they have ruled on (Durling, 2003; Sykes, 2003). ${ }^{3}$ Finally, it is important to point out that the record of successful WTO challenges is not due to learning difficulties

\footnotetext{
${ }^{1}$ Note that these numbers are rough measures as there are frequently examples of both multiple disputes covering the same imposed remedy (e.g., the 2002 U.S. safeguard over steel led to nine separate disputes being initiated) and multiple trade remedies being challenged in a single dispute (e.g., United States - Laws, Regulations and Methodology for Calculating Dumping Margins ("Zeroing”), DS294, which challenged 21 separate U.S. trade remedies).

${ }^{2}$ To the extent that WTO members desire reform of the agreements covering trade remedies, an increased frequency of initiated disputes may be a negotiating tactic to increase visibility and the likelihood that they receive a place on the negotiating agenda during the ongoing round.

${ }^{3}$ Durling (2003, p. 131) notes that for disputes over antidumping measures, in 12 of the 13 cases that reached the panel stage between 1995 and 2002, panels found at least some WTO inconsistency. For cases in which a United States antidumping measure was at issue, the record is 6 out of 7 WTO disputes. Sykes (2003) discusses WTO rulings on challenged safeguard actions, and Cunningham and Crib (2003) discuss WTO rulings on U.S. countervailing duty cases.
} 
that might face relatively inexperienced "new users" of trade remedy laws. To the contrary, the successful legal challenges to trade remedies have largely targeted developed countries with a history of trade remedy use, i.e., countries with the most experienced bureaucratic agencies that administer trade remedy investigations with resources and access to potentially sophisticated legal (and economic) analysis. The implication is that the measures being successfully challenged are imposed by countries whose trade remedy laws serve as models that countries new to establishing their own statutes and investigative procedures are quick to emulate.

From this perspective, i.e., given the relatively transparent process through which a trade remedy action is implemented, the increasing frequency with which trade remedies are applied worldwide, and the fact that virtually all challenged measures that proceed to a Panel and/or Appellate Body decision are found to have some inconsistency with WTO standards, the more poignant research question is, why have so few of these applied trade remedies actually been challenged at the WTO? ${ }^{4}$ What factors influence an adversely affected country's decision of whether to formally challenge an imposed trade remedy through formal dispute initiation at the DSU?

This paper is a first attempt to empirically investigate determinants of WTO members' decisions of whether to challenge an imposed trade remedy through a formal WTO dispute. The fact that not all imposed trade remedies are challenged at the WTO suggests that governments undertake a calculus and only pursue actions in which the expected benefit to a WTO dispute outweighs the expected cost. The expected benefit would be jointly determined by the size of restored import market access should the importing country remove the remedy, ${ }^{5}$ combined with the probability of restoration of market access. The probability of restored market access is determined by the likelihood that the respondent would comply with Panel and/or Appellate Body decisions upholding a successful challenge,

\footnotetext{
${ }^{4}$ This has similarities to a question raised by Blonigen and Prusa (2003) in their survey of the economics research literature of antidumping. They observe that given the ease of apparent access to antidumping protection and "[d] espite the statistics ... detailing the substantial and growing use of AD [antidumping] laws, one question is why there aren't more AD filings." On the other hand, some commentators have argued that too many U.S. remedies have been challenged at the WTO, and that WTO rulings on U.S.-imposed remedies (and the concern for the Appellate Body's "judicial activism") in particular may have long-term implications for U.S.-willingness to participate in the system. For commentary along these lines, see Tarullo (2003) or Greenwald (2003).

${ }^{5}$ For a basic economic discussion of the WTO as a forum for countries to exchange market access concessions based on the principle of reciprocity, see Bagwell and Staiger (2002, chapter 4). Unlike many other disputed policies that may be applied on a most-favored-nation (MFN) basis, the expected benefit to a complainant has minimal tradeassociated "externalities," given that the vast majority of trade remedies are applied on a discriminatory (i.e., country-specific) basis, which should thus serve to reduce the free-rider problem affecting the optimal amount of litigation. For a discussion of some of the economic implications of the WTO's nondiscriminatory MFN principle, see Bagwell and Staiger (2002, chapter 5). In dispute settlement cases over trade remedies there may be procedural externalities, however, if the legal decisions made in a case establish precedent that discourages future trade remedies (as they would also be inconsistent with GATT/WTO standards) against other countries.
} 
where compliance may also be a function of a credible threat of the complainant retaliating through the DSUsanctioned withdrawal of concessions. On the other hand, the expected costs to pursuing a case could include both the resource costs associated with litigation, as well as the political-economic costs associated with challenging the remedy-imposing country through formal international dispute settlement. Finally, there may also be a procedural cost if the litigation were to establish a precedent that would also require the complainant to change the way in which it pursues trade remedies in its own import markets.

We propose and empirically test whether there are political and economic motives to explain the pattern of challenges to trade remedies through formal WTO dispute settlement activity when compared to those remedies that are not challenged. As a first pass at this question, we construct a sample of all U.S. trade remedy actions against WTO members falling under its antidumping and countervailing duty laws between 1992 and $2003 .{ }^{6}$ We argue that there are a number of reasons that motivate this as a useful initial investigation. ${ }^{7}$ First, as we illustrate in tables 2 and 3, there is a substantial amount of variation in trade remedy actions imposed by the United States over this time period - remedies target many different WTO members and were challenged by a reasonable cross-section of those affected countries. ${ }^{8}$ Second, unlike the WTO membership at large, we have very detailed data on the full set of U.S. trade remedy actions and their WTO challenges - including data on the policies as well as detailed data on the products and industries affected. Third, by focusing initially on one trade remedy-imposing country (the U.S.), we are able to implicitly control for remedy-imposing country characteristics. Fourth, and as previously mentioned,

\footnotetext{
${ }^{6}$ We will not empirically investigate U.S. safeguard actions (neither Section 201 nor "transitional" safeguard actions for textiles, agriculture, or China) that have also been called into question at the WTO, though this is also clearly an area of research interest. One reason for not examining Section 201 cases here is that they are applied on a (quasi-) MFN basis, so that we would also have to address the free rider problem. Based on the approach undertaken here, there is also an empirical problem due to a lack of variation in the data, given that all U.S. safeguard measures implemented under Section 201 since 1995 have been challenged at the WTO (though the 1996 U.S. safeguard on broom corn brooms brought by Colombia did make it only as far as the consultations stage). We leave for future research the question of WTO challenges to U.S.-imposed safeguard measures.

${ }^{7}$ To clarify, in this paper we focus only on the foreign decision of whether to challenge an imposed U.S. trade remedy at the GATT/WTO. There are other potential areas in the litigative process in which parties could also challenge the imposition of a remedy, including during the actual U.S. investigation, after an affirmative ruling at the U.S. Court of International Trade, and at NAFTA panels for remedy investigations involving Canada or Mexico. While all of these areas of the litigative process are of research interest, we focus exclusively on potential challenges at the GATT/WTO here.

${ }^{8}$ In our discussion that follows below, we will use the terms "GATT/WTO" and "WTO" interchangeably. Though as table 2 clearly illustrates, while some of the trade remedy investigations may have taken place at the very end of the GATT period, the virtually all of the dispute settlement challenges in our data set have taken place during the WTO period under the DSU.
} 
while our focus on one remedy-imposing country does obviously impose a limit on the extent to which one can extrapolate from our results to lessons for other remedy-imposing countries; nevertheless, the United States' trade remedy laws and procedures in particular serve as a model that many other WTO members emulate as they construct their own provisions. Thus lessons learned from the U.S. experience and interaction with WTO dispute settlement may arguably have implications for other international users of trade remedies as well.

Table 4 uses the U.S. data on trade remedies to illustrate a number of comparative results that our formal econometric investigation formally seeks to confirm. First, and perhaps not surprisingly, a U.S. trade remedy that leads to the loss of a large value of imports in the U.S. market is more likely to result in a measure being challenged than one resulting in the loss of a small value of imports. This is consistent with the first row of table 4, which shows that the mean level of lost imports in WTO-challenged measures is $\$ 49.9$ million, relative to $\$ 3.2$ million for nonchallenged U.S. remedies. Second, we also find that the capacity for the foreign country to retaliate over U.S. exports should it "win" the case is also associated with a higher probability of it bringing forward a dispute in the first place. This is illustrated by a simple comparison made in table 4, where the mean share of U.S. exports sent to countries that challenge trade remedies is $16.9 \%$, whereas the U.S. is less reliant on the average country that does not formally challenge a U.S. remedy at the WTO, as that country receives only $6.5 \%$ of U.S. exports.

We also investigate and provide evidence of a second avenue through which the capacity for retaliation threats matters, and we find that this avenue could be serving as a substitute to formal WTO dispute settlement proceedings. The data suggests a strong negative relationship between a WTO dispute filing and the foreign industry's capacity to directly retaliate against the U.S. industry through a reciprocal antidumping investigation and measure of its own. Consider the destination of the production of the U.S. industry that receives the protection from the initial U.S. trade remedy. Table 4 illustrates that the share of the value of that production that is exported to the affected foreign country is higher $(0.9 \%$ versus $0.7 \%)$ in the average case in which the foreign country does not file a WTO complaint. This evidence is consistent with the hypothesis that WTO dispute settlement procedures and the foreign country's own antidumping law can serve as substitute policy instruments. Thus some exporting countries that are affected by U.S. trade remedies may be choosing "vigilante justice" and directly targeting their U.S. competitors with antidumping actions, in lieu of convincing their government to confront the U.S. with a formal WTO dispute. Finally, we also note the relationship between this phenomenon and the idea first proposed by Prusa (1992), that antidumping law may inadvertently serve as a device that facilitates collusion between foreign and 
domestic firms. The nature of the collusion noted by Prusa (1992) stemmed from the empirical regularity that domestic firms frequently withdrew from U.S. antidumping investigations shortly after their initiation, and the argument was that some firms had merely initiated investigations in order to communicate economic information to foreign competitors without risk of prosecution under a U.S. antitrust exception called the Noerr-Pennington doctrine. Here the collusive behavior of domestic and foreign firms could be facilitated by the reciprocated use of antidumping laws across countries, if it is serving as a way for one country's industry to either discipline foreign competitors (i) that have deviated from a collusive outcome, or (ii) into observing a collusive outcome. ${ }^{9}$

We also document a number of other interesting results in the data. First, countries that are less diversified (i.e., more reliant on the U.S. for their export market) for their remedy-affected exports are also less likely to challenge the U.S. trade remedy. This is also illustrated on table 4 , where, on average, $63.0 \%$ of pre-remedy exports are sent to non-U.S. markets in challenged cases, whereas only $45.0 \%$ of pre-remedy exports are sent to third markets in the average non-challenged case. This is of potential concern given that non-diversified exporters may be the least likely to "deflect" lost exports to third markets, perhaps because they lack the prior experience of overcoming any fixed cost associated with exporting to alternative markets. In a global welfare context, this could make the impact of a U.S. trade remedy especially burdensome. Finally, unlike the results of other related research, we find no evidence that, holding other things constant, our measure of a foreign country's limited "legal capacity" negatively affects the decision to participate in a dispute against a potentially WTO-inconsistent policy.

In addition to its relevance for the research literature on trade remedies and the antidumping process in the United States, this paper also contributes to the empirical literature on formal dispute settlement in the GATT/WTO system, which has largely focused on other elements of the dispute resolution process. ${ }^{10}$ One important and

\footnotetext{
${ }^{9}$ We should also note that there are a number of reasons why antidumping retaliation would be preferable to a WTO dispute from the perspective of the negatively affected foreign industry. First, to the extent that an antidumping law is simply a bureaucratic process that is largely exempt from political influences, the industry may find that direct antidumping retaliation provides a more certain outcome than attempts at convincing its national government to take up a case against the U.S. on its behalf at the WTO. Furthermore, antidumping retaliation would be more likely to directly benefit the foreign industry, whereas even DSU-sanctioned retaliation against the U.S. could be sought after and authorized as the withdrawal of concessions over a completely separate sector, thus providing no gains to the foreign industry negatively affected by the initial U.S. remedy.

${ }^{10}$ Bown (2004a), for example, provides an empirical investigation into determinants of the economic outcomes of the GATT/WTO dispute resolution process for 1973-1998. See Busch and Reinhardt (2001) for a political science perspective. With respect to economic investigations of the potential bias in participation in the WTO's dispute settlement process, see Horn et al. (1999), Holmes et al. (2003) and Bown (2004b). For a discussion of capacity constraints affecting developing country participation in the U.S. antidumping process in particular, see Bown et al. (2003).
} 
unresolved research question, however, concerns "access" to dispute settlement activity, and whether the use of WTO dispute settlement may be biased against the initiation of cases by smaller, poorer, or developing countries in particular. The standard problem for a researcher seeking to address this question is data - we are unable to observe the full set of "WTO-inconsistent" activity that WTO members undertake, and thus we cannot directly test whether there is a bias in which subset of this activity actually gets reported to the WTO through formal dispute settlement channels. Here we partially address this question by supposing that "all" U.S. trade remedy actions were WTOinconsistent, and under this scenario, examining whether there is a pattern to the initiation of disputes over imposed measures to search for evidence of any bias against dispute initiation by important country and industry characteristics.

The rest of this paper proceeds as follows. In the next section we describe some of the basic institutional features of WTO-authorized trade remedy laws, as well as provide a brief discussion of their economic motivation. In section 3 we present the basic expected cost-benefit framework that we use to guide our empirical approach investigating determinants of whether a U.S. trade remedy action is challenged at the WTO, as well as a description of the underlying data used for the analysis. Section 4 presents our formal econometric model, including the selection equation approach used to address the potential concern for sample selection bias. Finally, section 5 presents our econometric results, and section 6 concludes with a discussion of additional caveats and areas for further research.

\section{Institutional Background for Trade Remedies: Law and Economic Theory}

\subsection{Economic Motivation for Trade Remedy Laws}

Economists typically decry an implemented trade remedy as import protection that generates welfare inefficiencies and acts as little more than a second-best policy instrument. Nevertheless, economic theorists have rationalized the ex ante inclusion of some form of permissible national trade remedy law into negotiated international trade agreements through at least two reasons. While traditionally motivated through inclusion of a safeguard clause allowing for the temporary suspension of certain elements of the liberal trade agreement, economists justify this on the grounds of what Hoekman and Kostecki (2001) refer to as either the "insurance" or 
"safety valve" motives. ${ }^{11}$ The insurance motive suggests that without such safeguard provisions, governments may be hesitant to sign trade agreements that lead to substantial liberalization. The safety valve motive suggests that governments may feel pressure to renege on certain negotiated liberalization commitments, and therefore safeguards are necessary to protect the integrity of the rest of the agreement.

WTO members have infrequently utilized the formal GATT/WTO safeguard provisions over the agreements' histories, instead appealing to the other trade remedies such as antidumping and countervailing duty provisions under the WTO and voluntary export restraints and other "grey-area measures" under the GATT, that have since been banned under the WTO. ${ }^{12}$ While there are many procedural differences between them, we work from the assumption that there is substitutability between the trade remedy instruments that are used by injured industries and then policymakers seeking an escape from the constraint of the GATT/WTO agreement that prohibits them from otherwise unilaterally raising trade barriers above negotiated tariff binding levels.

\subsection{National Trade Remedy Laws and GATT/WTO Agreements}

Under the GATT 1947 regime, antidumping and countervailing duties were initially authorized under Article VI, which was somewhat expanded in the Tokyo Round to the plurilateral Antidumping and Subsidies Codes. Under the WTO, the provisions relating to antidumping and countervailing duties are now part of the Single Undertaking that applies to all WTO members under the Agreement on Antidumping and the Agreement on Subsidies and Countervailing Measures. Safeguards for the temporary protection of imports were originally authorized under the GATT's Article XIX, and in 1995 were also more completely developed under the WTO's Agreement on Safeguards.

\footnotetext{
${ }^{11}$ See also Sykes (1991) and the discussion in Bagwell and Staiger (2002, chapter 6), as well as Bagwell and Staiger (2004).

${ }^{12}$ For a discussion of the economic incentives generated by the WTO rules on safeguards and antidumping in particular, which suggests that they might be acting as substitutable policy instruments, see Bown (2002).
} 


\subsection{The History of GATT/WTO Dispute Settlement over Trade Remedies}

The first formal GATT trade dispute over antidumping that resulted in a panel was initiated by Italy against Swedish antidumping duties on nylon stockings in $1954 .{ }^{13}$ Nevertheless, until the early 1990 s, countries infrequently challenged antidumping measures under the GATT's formal dispute settlement provisions. The first GATT case against a U.S. antidumping action resulting in a panel report was not filed until 1988, under the dispute settlement provisions of the Tokyo Round's Dumping Code. ${ }^{14}$ There were a handful of disputes filed against U.S. imposition of countervailing duties in the 1980s under the Subsidies Code and the GATT's Article XXIII, including the first highprofile disputes over U.S. countervailing duties on imports of Canadian softwood lumber. Nevertheless, the trend of infrequent formal challenges to trade remedies continued through the end of the GATT period in the early 1990s.

With the establishment of the WTO's Single Undertaking in 1995 and the full integration of the Agreements on Antidumping, Subsidies and Countervailing Measures, and Safeguards, as well as the establishment of the Dispute Settlement Understanding, trade remedies have been a frequent and increasing target of dispute settlement activity. Once again, table 3 illustrates the U.S. trade remedy actions undertaken between 1992 and 2003 that were challenged with an initiated trade dispute at the GATT/WTO.

\subsection{The Importance of WTO Dispute Settlement over Trade Remedies}

The decisions made by the WTO Panels and the Appellate Body have sparked a substantial literature by legal and economic scholars (Sykes, 2003; Irwin, 2003). One particular area of concern is the consistency between national and WTO standards of review in trade remedy investigations, as well as the concern for whether WTO legal decisions are not just striking down imposed remedies, but also providing guidance for what would be an appropriate methodology for the imposition of national trade remedies that would pass WTO standards. Even though the ultimate imposition of a remedy leads to the distortion of trade, the misallocation of resources, and national welfare losses; nevertheless, scholars have argued that it may be important to define the characteristics of a WTOconsistent trade remedy that would stand up to a dispute settlement challenge if such remedies are indeed an

\footnotetext{
${ }^{13}$ Swedish Antidumping Duties (L/328 - 3S/81) Report adopted on 26 February 1955.

${ }^{14}$ United States - Imposition Of Anti-Dumping Duties On Imports Of Seamless Stainless Steel Hollow Products From Sweden - Report of the Panel (ADP/47).
} 
important feature helping to sustain the overall liberal trade bargain struck between countries in the GATT/WTO system (see again Bagwell and Staiger, 2002 and 2004; Sykes, 1991; Hoekman and Kostecki, 2001).

\section{$3 \quad$ Economic Theory: When to Challenge a U.S. Trade Remedy at the WTO?}

\subsection{The Sample of Challengeable U.S. Trade Remedies}

Our question of interest is the determinants of a WTO member's decision of whether to formally challenge a U.S. trade remedy that was imposed in year $t$, where the year of the remedy falls in the 1992-2003 period. All of the data on U.S. antidumping and countervailing duty actions have been compiled from the publicly available U.S. government publication, the Federal Register. This publication documents the country of the firms under investigation, the 10-digit Harmonized Tariff System (HTS) product codes of the products under investigation, the dates of the phases of the investigation, the outcomes of various phases of the investigation, and the level of applied duties in affirmative cases. We include all trade remedy actions that either ended in the U.S. application of duties or through a suspension agreement, implicitly assuming that all such remedies were "challengeable" at the WTO. ${ }^{15}$

Our hypothesis is that a country that is targeted by a U.S. trade remedy will initiate a formal WTO trade dispute and contest the measure if the expected benefit to a dispute are greater than its expected costs. We assume that the expected benefit depends on the size of the gains the foreign country receives from a successfully resolved case as well as the probability that the case will be resolved successfully. We allow for the expected costs of dispute initiation to be made up of two separate elements that include both the expected litigation costs and the expected political-economic costs to confronting the United States in a formal dispute. As we describe in more detail below, our hypothesis allows for economic interests to affect decisions, but we also include proxies for some of the institutional biases that WTO scholars have been concerned might also influence a country's ability to stand up for its market access interests.

The primary alternative hypothesis to the one we pursue here is that imposed trade remedies are not formally challenged under dispute settlement proceedings because of the Agreement on Antidumping's Article 17.6 requirement that WTO Panels show deference to national authorities' decision-making during antidumping

\footnotetext{
${ }^{15}$ We will only be able to use cases involving manufacturing products due to our need to control for injury (requiring industry-level data, which is not comparably available for agricultural products.) This does not severely restrict the size of the sample, however.
} 
investigations. ${ }^{16}$ The failure to find evidence of our political economic determinants affecting the WTO-challenge decision would be consistent with the theory that the WTO membership is acting rationally and not challenging cases that would either have high market access gains and/or which would could be litigated at relatively low cost, because they anticipate that dispute settlement panels would indeed show "deference" and follow Article 17.6, thus placing an extraordinarily low probability on the expectation of a successful legal outcome to the case.

We classify a U.S.-imposed trade remedy as being challenged if we can find evidence of a formal dispute being initiated under the GATT or WTO. We consider all challenges to U.S.-imposed remedies, whether the challenge concerns the investigation of dumping, subsidies, or injury, or whether it is an investigation during an administrative or sunset review. Most of the data on which trade remedies were formally challenged by foreign countries through GATT/WTO dispute settlement proceedings are also available in publicly available data bases. For example, the WTO's website has all of the data on formal disputes covering the period since 1995, as well as some antidumping and countervailing disputes that resulted in formal panel reports under the GATT period. A handful of antidumping and countervailing duty disputes that took place under the dispute settlement provisions of the Tokyo Round Codes were pieced together by examining unpublished GATT documents. The summary of these GATT/WTO challenges to U.S. trade remedies imposed over the 1992-2003 period is listed in table 2.

In the next two sections we detail the variables and data we use to represent the expected benefits and costs of our empirical investigation.

\subsection{Expected Benefits to Initiating a Dispute}

\subsubsection{Exporter market access benefits from a successful dispute}

What are the expected benefits to initiating a dispute against a U.S.-imposed trade remedy, and when would they be large? For the purpose of this investigation, we focus on the direct, short-term economic benefits to participating in the dispute, i.e. the improved terms of market access that would result if the U.S. removed the trade remedy in question. Thus, we expect a foreign country is more likely to initiate proceedings when it has lost a substantial amount of trade due to the U.S. remedy. Given that the imposition of many U.S. remedies has a

\footnotetext{
${ }^{16}$ Formally, Article 17.6(i) states that when a WTO panel reviews the national authority's antidumping investigation and decisions, "[i]f the establishment of the facts was proper and the evaluation was unbiased and objective, even though the panel might have reached a different conclusion, the evaluation shall not be overturned..."
} 
prohibitive impact on imports (Staiger and Wolak 1994; Prusa 2001; Bown 2004c), we use as our proxy for lost imports the log of the value of 10-digit Harmonized Tariff Schedule (HTS) imports of the targeted product in year $t$ 1, i.e. the year before the trade remedy was imposed. The 10-digit HTS import data for the United States comes from Feenstra, Romalis and Schott (2002) and updates from the ITC's DataWeb database.

Second, the removal of the U.S.-imposed trade remedy may not be particularly important to some exporting countries that have substantial access to alternative export markets and can thus "deflect" trade that is eliminated from the U.S. to other markets. ${ }^{17}$ Put differently, the removal of the U.S.-imposed remedy may be more beneficial to a less-diversified exporter than to a more-diversified exporter. To address the possibility that this affects the WTO litigation decision, we include as an additional explanatory variable the share of the exporter's product-level exports to the non-U.S. markets in $t-1$ relative to its total product-level world exports of the goods targeted by the U.S. remedy. ${ }^{18}$ We expect this variable to be negatively related to the decision of whether to initiate a dispute - a country that is highly diversified (i.e., with a large share of remedy-affected exports already being exported to third markets), should be less likely to challenge a U.S.-imposed remedy at the WTO, because it more easily shift those lost U.S. exports to such third markets.

Third, we also include the level of the U.S.-imposed trade remedy in the case, which we define as the trade weighted-average final duty reported in the Federal Register. We are admittedly agnostic as to how this variable would affect the likelihood of WTO dispute initiation. While an extremely high duty may also be more likely to indicate an egregious WTO violation (affecting the likelihood of legal success in the dispute, to be discussed in more detail below), there may be a substantial range through which even lowering that duty would still leave it as prohibitive, resulting in a zero market access benefit to the affected exporter for initiating a WTO-challenge. On the other hand, while a lower imposed duty may be less likely to be WTO-inconsistent, a marginal reduction could have a substantially positive market access impact.

\footnotetext{
${ }^{17}$ For evidence on exporting countries ability to "deflect" U.S. trade remedy-affected exports to third markets, see Bown and Crowley (2004).

${ }^{18}$ Since we are comparing the foreign exports to the non-U.S. markets relative to foreign exports to the world (at the product level), we can no longer use the 10-digit HTS import data as our level of aggregation. Thus, for this variable we use the 6-digit, product level Harmonized System (HS) data derived from the UN's COMTRADE database, as this is the most disaggregated trade data that is readily comparable across countries. Nevertheless, this data is only consistently available for 15 of the world's 30 largest importing countries for the 1992-2003 period required for our sample; therefore, in constructing the ratio, the foreign country's exports to the "rest of the world" are proxied for by the imports of the following 14 other countries: Australia, Brazil, Canada, Switzerland, China, Germany, Denmark, Japan, Mexico, Malaysia, Singapore, Sweden, Turkey and Taiwan.
} 


\subsubsection{The likelihood of success in a dispute}

Another element relating to the size of the expected benefits are factors affecting the probability of a successful economic resolution to a potential WTO dispute. Due to the self-enforcing nature of the WTO's dispute settlement system, exporting countries can only enforce their rights through actual or implicit threats of retaliation against offending trading partners. ${ }^{19}$ Therefore, we hypothesize that a U.S. remedy is more likely to be challenged if the affected foreign country is bilaterally powerful (with respect to the U.S.) because this positively affects the probability of a successful economic outcome. Conditional on a "guilty" Panel and/or Appellate Body ruling, the U.S. may be more likely to bring its WTO-inconsistent policy into conformity with its obligations if there is a credible retaliatory cost for failing to do so. We therefore measure the capacity for the foreign country to credibly threaten a tariff retaliation by using the share of U.S. total exports sent to the exporting country. To construct this measure, we use the U.S. bilateral export data provided in Feenstra et al. (2002).

Finally, in an additional specification that serves as a robustness check, we utilize additional explanatory variables designed to capture whether the affected country can contribute economic evidence of the U.S. failure to show injury to the domestic U.S. industry in the initial trade remedy investigation. The failure to find injury would be evidence to support the claim that U.S.-imposed remedy was WTO-inconsistent which, ceteris paribus, would result in a higher probability of winning the case by having a DSU panel find in the complainants' favor. ${ }^{20}$ We will discuss details of variables used for these measures in section 4.2 below.

\subsection{Expected Costs to Initiating a Dispute Against the U.S.}

In this section we consider the basic litigation costs to filing a formal complaint against a U.S. trade remedy. ${ }^{21}$ When would the expected resource costs to an exporting country of formally initiating a dispute against

\footnotetext{
${ }^{19}$ Using a sample of GATT/WTO disputes initiated and completed over the 1973-1998 period, Bown (2004a) has shown that the more powerful is the complainant exporter with respect to its capacity to engage in tariff retaliation against the respondent, the greater are the trade liberalization gains that the respondent yields to the complainant at the conclusion of the dispute.

${ }^{20}$ As Sykes (2003) and Irwin (2003) point out in related safeguard cases which also have an injury requirement, merely showing evidence of injury is not sufficient, the WTO Appellate Body in particular has been concerned with evidence attributing injury to imports.

${ }^{21}$ In our robustness checks described in section 5.2.4 below, we also investigate measures of political economic costs that may affect the litigation decision as well.
} 
the U.S. be high? The litigation costs of merely initiating a case as a complainant are not large, and that is the only indicator necessary for our analysis of whether a U.S. trade remedy is challenged at the WTO. Nevertheless, we do proxy for the foreign country's capacity to incur significant legal costs by using measures of its real GDP per capita, with data derived from World Bank (2004). We feel that this is a reasonable measure and is likely better than one designed to capture the stock of lawyers in the foreign country, given that legal expertise is an internationally traded service. Nevertheless, we also proxy for a country's legal capacity by using data on the number of delegates the WTO member had sent to the Secretariat in Geneva. The larger are each of these variables, the greater the country's capacity to absorb legal costs and the more likely it will initiate a dispute, ceteris paribus.

\subsection{Access to Alternative Retaliatory Instruments}

Our last explanatory variable included in this stage of the estimation is designed to capture the concern that a country may choose not to use the formal dispute settlement process at the WTO to challenge a U.S.-imposed trade remedy because it has access to an alternative (and perhaps preferable) retaliatory instrument, i.e., because it is able to take matters into its own hands and hit the protected U.S. industry with a trade remedy of its own. Therefore, we include another measure which is the share of the U.S. industry's value of domestic production that is exported to the remedy-affected country, where the industry is the 6-digit NAICS industry that is receiving the U.S. trade remedy protection. ${ }^{22}$ The higher is the share of the value of U.S. industry production exported to the foreign country, the less likely is the foreign country to initiate a formal WTO dispute against the U.S. because it can discipline the U.S. industry directly through its own appeal to a trade remedy investigation. The industry level production data is the value of shipments data taken from the NBER Manufacturing Industry Productivity Database for the 1991-1996 period, while for 1997-2002, the data was taken from individual, industry level reports in the U.S. Census Bureaus' publication, 2002 Economic Census, Manufacturing Industry Series. ${ }^{23}$

\footnotetext{
${ }^{22}$ The U.S. 6-digit NAICS export data is also taken from Feenstra et. al (2002). Blonigen and Bown (2003) have found evidence that the capacity for foreign antidumping retaliation threats affects an earlier stage of the antidumping process, i.e., the question of which foreign countries are to be named in an antidumping investigation. Their results suggest that, ceteris paribus, a U.S. industry is less likely to name a foreign country on whom its market it is particularly reliant for its own exports.

${ }^{23}$ We have also interacted this variable with an indicator for whether the WTO member has an antidumping law, but this makes little difference as virtually all WTO members in the sample of countries hit with a U.S. remedy had an antidumping law in place.
} 
The summary statistics for each of these variables used in the estimation are provided in the rows of the lower half of table 5 .

\section{Econometric Approach}

\subsection{Econometric Model}

Our ultimate question of interest is why foreign governments choose to challenge some U.S. trade remedies while not challenging other U.S. measures. To address this question, our sample of data consists of the set of U.S. trade remedy actions imposed after antidumping and countervailing duty investigations initiated between 1992 and 2003. We only focus on those applied against GATT Contracting Parties or WTO members, as formal participation in the GATT/WTO system is an obvious requirement for the foreign country's use of GATT/WTO dispute settlement procedures. Our empirical investigation will thus examine determinants of a dichotomous dependent variable which takes on a value of 1 if a U.S. trade remedy was challenged by a WTO trade dispute and 0 if it was not. In the absence of any additional econometric concerns, we would simply estimate the probability that a U.S. trade remedy was challenged by assuming that the decision was a function of a number of covariates with a normally distributed error term, and we would thus employ the standard probit model.

However, one concern with examining in isolation the foreign country's decision of whether or not to file a GATT/WTO dispute over a U.S.-imposed trade remedy is selection bias. ${ }^{24}$ In our case, selection bias results from the incidental data truncation problem associated with the fact that we only observe formal trade disputes over U.S. trade remedy investigations that would ultimately result in the trade remedy being applied. For example, one of our key testable hypothesis is that a foreign country is more likely to file a WTO dispute against the U.S. if it has a sufficient retaliation capacity, and thus we presume that this may have a direct effect on our underlying dependent variable of interest. However, given the evidence provided by Blonigen and Bown (2003), we would also expect that the same retaliation capacity may also affect the likelihood that the U.S. imposes a trade remedy against that particular foreign country in the first place, and thus it also has an indirect affect on the probability that this country

\footnotetext{
${ }^{24}$ For a further discussion of the selection bias problem in econometrics, see Greene (2000, pp. 926-950).
} 
is in our sample of countries facing a U.S. trade remedy. Thus failing to allow for the indirect effect of this variable could lead to biased estimates of the direct effect. ${ }^{25}$

To address the concern of selection bias resulting from the idea that the set of U.S. trade remedies over which a foreign country has faced a tariff is not random, we use a Heckman (1979) style correction procedure and introduce a selection equation accounting for the U.S. government's decision of whether or not to impose a trade remedy on a GATT/WTO member country after an industry-initiated investigation. For our purposes, the standard Heckman procedure needs to be modified to address the fact that both the selection equation (U.S. protects or doesn't protect an industry petitioning under the trade remedy laws) and the regression equation of interest (foreign country challenges or doesn't challenge the U.S. remedy with a formal WTO dispute) have dichotomous (as opposed to continuous) dependent variables. Therefore, we use the Van de Ven and Van Praag (1981) probit application of the Heckman (1979) selection bias correction procedure.

\subsection{Additional Variables and Data for the Selection Equation}

Finally, in order to estimate the selection equation, we require additional explanatory variables that are not necessarily of interest to our question of the determinants of the foreign country's decision of whether it will challenge any imposed measures with formal dispute settlement proceedings. Nevertheless, we have collected industry and country-level data on the standard political and economic variables that others (e.g., Hansen and Prusa, 1996; 1997) in the literature have shown to be determinants of the U.S. authority's decision-making process. These include variables on the change in industry employment, level of industry employment, the import penetration ratio, the growth rate of investigated imports in the period prior to the investigation, the concentration ratio of the domestic industry, the change in the industry's capacity utilization rate, as well as retaliation capacity (Blonigen and Bown, 2003). ${ }^{26}$ We expect there to be a negative relationship between the change in industry employment and the

\footnotetext{
${ }^{25}$ This may also be the case if evidence of injury to the domestic industry makes it more likely that a petitioning industry will receive trade remedy protection and thus increasing the probability of being in the sample, and yet the evidence of injury makes it less likely that the measure will be challenged with a formal trade dispute. We will investigate this potential outcome and discuss this further in section 5.2.3 below.

${ }^{26}$ Capacity utilization rate for the associated 6-digit NAICS (4-digit SIC) industries are found in the U.S. Bureau of the Census' Current Industrial Reports, Survey of Plant Capacity. Four-firm concentration ratios are available form U.S. Bureau of the Census publication, U.S. Census of Manufactures, Concentration Ratios in Manufacturing. Data on the industry level value of shipments and industry-level employment are taken from the NBER Manufacturing Industry Productivity Database for the 1991-1996 period, while for 1997-2002, the data was taken from individual,
} 
change in the capacity utilization rate (standard injury determinants) with the probability that the U.S. authorizes trade remedy protection to a petitioning industry. On the other hand, we expect a positive relationship between the U.S. protection decision and explanatory variables such as the import penetration ratio, the level of industry employment and the four-firm concentration ratio of the industry. These last two variables are commonly used to proxy for the political importance of the industry, as well as the industry's ability to overcome the free-rider problem to organize and successfully petition for protection.

\section{$5 \quad$ Estimation Results}

In this section we discuss the results from maximum likelihood estimation of the probit model with selection. Even though the two equations are estimated simultaneously, for ease of exposition we split our discussion of the two separate stages into two separate parts. In the first section we briefly describe the results from the selection equation (reported in table 6a), before turning to the results of the question of interest in section $5.2-$ determinants of the foreign country decision of whether to challenge a U.S.-imposed trade remedy at the WTO (reported in table 6b). The first specification (1) in each table uses the baseline sample of U.S. antidumping investigations and measures imposed on GATT/WTO members over the 1992-2003 period, the second specification (2) adds the sample of countervailing duty investigations and measures imposed, and the third specification (3) is a robustness check that allows for industry injury determinants to also affect the WTO-challenge decision.

\subsection{Selection Equation: Determinants of Which U.S. Investigations Against GATT/WTO Members End in Trade Remedies}

Table 6a shows the results for determinants of the selection equation decision of whether the U.S. investigation of a GATT/WTO member under its antidumping or countervailing duty laws results in affirmative findings (injury and dumping and/or subsidies) and thus a trade remedy. While most of the estimates for the explanatory variables have the sign that is predicted by theory, only three of the estimates are statistically significant at conventional levels. In the sample of investigations of products deriving from WTO members shown in column (1), the U.S. is more likely to impose an antidumping measure the higher the import penetration ratio (2.729) and the

industry level reports published in the U.S. Census Bureaus' series, 2002 Economic Census, Manufacturing Industry Series. 
less reliant is the U.S. on the targeted foreign country for its own exports $(-0.720)$. In specification (2), the U.S. authorities are also more likely to impose a trade remedy, the larger is the recent surge in product-level imports under investigation (0.107). The only estimates that run counter to the theory are the variables designed to capture the "injury" to the domestic industry (change in employment, change in capacity utilization), though these estimates are not statistically different from zero. ${ }^{27}$ Since the estimates presented in table 6a are not of particular concern to the ultimate question of interest regarding the question of whether to formally challenge a U.S.-imposed remedy at the GATT/WTO, we will not further discuss them here.

\subsection{Regression Equation: Determinants of Foreign Country Decisions to Formally Challenge a U.S. Remedy with a WTO Dispute}

Table $6 \mathrm{~b}$ provides results from our estimation of the decision of a foreign country to challenge a U.S.imposed trade remedy at the WTO.

\subsubsection{Expected benefits and costs to dispute initiation}

Consider initially the first three rows of table $6 \mathrm{~b}$ which describe whether the size of the market access benefits from the U.S. removing the imposed trade remedy are associated with the WTO member's decision to formally challenge the measure with a dispute. First, the size of lost imports matters. The larger the dollar value of the investigated products in the U.S. import market in $t-1$ (the year before the trade remedy investigation), the more likely is the affected foreign country to challenge the measure (0.056). Since the import data is converted to logs the size of the effect is not particularly easy to interpret. Nevertheless, the impact of an increase from the mean value of the explanatory variable of 16.857 (the log of roughly $\$ 21$ million in targeted imports) to 17.857 (the $\log$ of roughly $\$ 57$ million in targeted imports, less than a one standard deviation increase) increased the likelihood of dispute initiation by 5.6 percentage points. Keeping in mind that the model's predicted probability at the means of the data is roughly a $10 \%$ likelihood of WTO dispute initiation, this is a sizable effect.

\footnotetext{
${ }^{27}$ A potential contributing explanation for the result that the "injury" determinants are not particularly successful in predicting antidumping decision-making is the sample of U.S. trade remedy investigations used in the estimation here - i.e., we only examine investigations against GATT/WTO members. For example, this implies omitting antidumping and countervailing duty investigations against China occurring before its WTO accession in 2001.
} 
On the other hand, there is an unexpected positive relationship (0.397) between how diversified the targeted foreign exporters are and their likelihood of filing a GATT/WTO trade dispute. We would expect a negative relationship - that the smaller is the share of the non-U.S. markets in the exporter's portfolio of export markets, the more likely is the exporter to spend the resources to challenge the U.S. trade remedy, because it is less readily equipped to deflect trade lost from the U.S. to third markets. Here the result is just the opposite (less diversified exporters are less likely to challenge U.S. trade remedies), which is potentially worrisome if it is indicative of a disproportionately large negative impact of U.S. trade remedies on such exporters. The size of the effect is also large - an exporter that is 1 percentage point more diversified is 0.397 percentage points more likely to initiate a dispute. Thus a one standard deviation increase in this variable increases the probability of dispute initiation to $24 \%$ relative to the $10 \%$ probability, when the model is evaluated at the means of the data.

The third row illustrates a negative relationship (-0.508) between the size of the imposed U.S. trade remedy and the likelihood of the remedy being challenged. This indicates that lower duties are more likely to be challenged, ceteris paribus, perhaps because they are non-prohibitive - each 1 percentage point reduction in the imposed duty increases the likelihood of dispute initiation by 0.508 percentage points.

Consider next the foreign country's capacity to retaliate which is our proxy for the likelihood of the U.S. complying with any panel and/or Appellate Body rulings that require it to provide additional market access to the exporting country. The more of the U.S.'s total exports are sent to the affected country, the more likely is the affected country to bring a dispute against the U.S. (1.676). This is consistent with evidence from other research that retaliation capacity affects decisions made in the U.S. antidumping process (Blonigen and Bown, 2003), as well as the likelihood of the successful economic resolution to a GATT/WTO trade dispute (Bown 2004a). Here, the size of the estimate indicates that, relative to the average trade-remedy affected foreign country, if the U.S. is one percentage point more reliant on the foreign country's markets for its total exports, the foreign country is 1.676 percentage points more likely to initiate a WTO dispute over a U.S. remedy.

Finally, there is little evidence from this sample of data and our proxies for "legal capacity" that any such limitations on legal resources negatively and systematically affect the decision to challenge an imposed U.S. trade remedy, once we control for other factors. If anything, the results are consistent with a negative relationship between the number of delegates at the WTO, GDP per capita and the question of whether to file a dispute at the WTO, though the impact is not statistically different from zero. 


\subsection{2 "Vigilante justice" through reciprocal antidumping instead of dispute settlement?}

One intriguing and robust result from table $6 \mathrm{~b}$ is the evidence on the "alternative retaliation instrument" that is consistent with the theory that when a foreign country is faced with dealing with a U.S.-imposed trade remedy, there is substitutability between WTO dispute settlement and the foreign country retaliating through an antidumping measure of its own. That is, there is a negative relationship (-7.129) between the foreign country's ability to retaliate through imposing an antidumping measure on the U.S. industry's exports (because the U.S. industry is reliant on the foreign country for its own exports) and that country filing a trade dispute at the WTO. The direct economic implication of the estimate is that, for a 1 percentage point increase in the share of the value of U.S. industry production (in the 6-digit NAICS industry protected with the U.S. remedy) sent to the targeted foreign country, there is a 7.129 percentage point decrease in the likelihood of the foreign country responding through initiation of a formal WTO dispute settlement challenge. This is a substantial effect, as the mean (standard deviation) of this variable in the underlying data is $0.8 \%(1.6 \%)$, meaning that a one standard deviation increase in this variable alone decreases the probability of the action being confronted with a trade dispute from roughly $10 \%$ to almost zero.

One explanation for this result is that the foreign industry's first choice after being hit with a U.S. trade remedy is to respond by initiating a trade remedy investigation of its own against its U.S. competitors. Then, if that is not possible, the industry resorts to the next best instrument, convincing its government to engage in formal, government-to-government litigation through a WTO trade dispute. Our results here are obviously an indirect test, measuring the foreign country's capacity to retaliate via antidumping against the petitioning U.S. industry. Furthermore, to the extent that senescent industries in the U.S. are frequent users of antidumping, such industries are not likely to be sufficiently competitive in world markets so as to have substantial exports, which thus limits the scope of reciprocal antidumping as a potential retaliatory instrument for foreign competitors. Nevertheless, for some capital intensive and cyclical U.S. industries that are globally competitive, the ability of the foreign industry to engage in reciprocal antidumping may be an alternative to attempts to convince its government to engage in formal WTO litigation. However, a direct test of this hypothesis would examine whether the foreign country actually retaliates with an antidumping action of its own. We do not pursue this direct test here for lack of currently available data on product-level, foreign antidumping actions against U.S. producers, and whether this is, indeed, a substitute policy instrument for filing a WTO trade dispute. We leave this important question for future research. 
Nevertheless, this result is consistent with related research investigating the global proliferation of antidumping in particular. First, the United States is not only one of the largest users of trade remedies worldwide. Zanardi (2004) notes that between 1991 and 2002, exporting firms from the United States were the third-most investigated producers worldwide in foreign antidumping investigations, as well as ranking third in number of instances of being hit with trade remedy measures (antidumping duties and price undertakings) worldwide, behind only China and Korea. Finally, Prusa and Skeath (forthcoming) examine the pattern of antidumping filings across the world and find evidence at the bilateral level of retaliation activity that is consistent with the indirect evidence described here, while Feinberg and Olson (2004) use the worldwide antidumping filing data to find evidence of such a relationship across 2 -digit industries as well. ${ }^{28}$

\subsubsection{Estimates for inclusion of countervailing duties, the injury determinants and without the control for selection bias}

The rest of table $6 \mathrm{~b}$ presents a number of initial robustness checks to our analysis. First, specification (2) adds in the additional observations for U.S. countervailing duty measures and their WTO challenges. Even after including these trade remedy observations as well, the basic pattern of qualitative results is unchanged.

In specification (3) of table $6 \mathrm{~b}$, we assess the importance of determinants expected to affect the injury decision in the U.S. trade remedy investigation (as described in table 6a) to check the robustness of our results. Inclusion of these variables in the second stage does not affect the qualitative pattern of results, and these variables are not of the expected sign and are not statistically significant. Part of the explanation for their poor performance is likely due to the fact that some countries are not challenging the injury investigation that took place in year $t$, but instead may be challenging a sunset or administrative review or a dumping or subsidy determination.

Finally, in specification (4) of table $6 \mathrm{~b}$, we re-estimate the probit regression equation of specification (1) solely, i.e., without the selection equation. The sign and size of the estimates are virtually unchanged from the earlier specification, suggesting that selection bias is not likely affecting the estimation in this particular application.

\footnotetext{
${ }^{28}$ Martin and Vergote (2004) develop a game theoretic model with private information between governments and industries in which reciprocal antidumping and the sort of "vigilante justice" described here occur on the equilibrium path.
} 


\subsubsection{Further robustness checks}

Table 7 provides a final set of additional robustness checks to further investigate the potential sensitivity of our results to alternative specifications. In particular, specification (5) uses an alternative variable in lieu of the measure of diversification of the foreign exporters targeted by the U.S. remedy. Instead, the variable is defined as the growth in (6-digit HS) exports of the targeted country to the rest of the world after the U.S. remedy has been imposed, i.e., its growth between $t$ and $t+1$. We expect the parameter estimate on this variable to be negative - the more the targeted exporters increase exports of the disputed product to third markets (proxying for whether they actually do "deflect" trade), the less likely would be the foreign country to litigate the issue of the U.S. remedy at the WTO. Nevertheless, the estimate is once again positive (though it is marginally insignificant), which provides some confirmation of our earlier result of concern that less diversified exporters are less likely to challenge measures at the WTO.

Next, in specification (6), we further investigate whether there is a link between political-economic relationships between countries and GATT/WTO dispute settlement filing behavior in this sample of data. In theory, a second potentially important expected cost to developing country exporters that may affect their decision of whether to challenge the U.S. at the WTO does not relate to the cost of litigation, but to the political economic costs of publicizing a grievance through a formal international confrontation with the U.S. One reason why the U.S. might be "important" is that the country affected by the trade remedy could be particularly reliant on the United States for bilateral assistance. Therefore, we expect the larger is the share of total aid received by the foreign country that derives from the U.S., the less likely is that country to initiate a dispute against the U.S. The bilateral aid data is derived from OECD (2001). In order to implement this, in specification (6) we also drop the foreign exporter's diversification variable, in case this is highly collinear with either the aid relationship or legal capacity variables so as to confound their estimated impact. While the results do indicate a negative relationship between the foreign country's reliance on the U.S. for bilateral aid and its dispute settlement decision, the size of the estimate is not statistically significant at conventional levels. Furthermore, the parameter estimates for the variables on legal capacity in specification (6) are also virtually unchanged, and the log likelihood is substantially higher than in the other specifications when the diversity variable is included. Thus, the lack of empirical importance of the proxies for the litigation costs and the political economy relationship stands in contrast to the evidence presented in the related research of Bown (2004b), which investigates the participation decisions of exporting countries adversely affected 
by nondiscriminatory but WTO-inconsistent trade policies under formal DSU litigation. That investigation found some evidence consistent with the hypothesis that legal capacity and political-economy relationships negatively affect the willingness of countries to engage in the dispute resolution process. That sample of data under investigation was much different, however, in that it analyzed WTO disputes initiated against a variety of countries (not solely the U.S.) that were applied on a quasi-MFN basis, thus negatively affecting many exporting countries.

The next two specifications (7) and (8) are crude attempts to address an econometric issue of the nonindependence of some of the observations in the estimation, given the pooling of the trade remedy data over time. ${ }^{29}$ The concern that we address in specification (7) is that the disputes involving an EU member country as a complainant are somehow driving the results. This could be the case given that there are a number of instances in which multiple EU-member countries are involved in related trade remedy investigations over the same product, which may make it more likely for those related cases to be jointly challenged at the WTO. For example, common elements (WTO-inconsistencies) across cases against different EU members could make it cost effective to spread the litigation burden across the member states. Nevertheless, when we include an indicator for the affected foreign country being an EU-member, the qualitative pattern of results are virtually unchanged, and the EU indicator itself is negative, though it is not statistically significant. ${ }^{30}$

Next, in specification (8) we attempt another approach, which is to include an indicator for the instances in which an imposed trade remedy is one of multiple remedies that the U.S. imposed against the same set of products from any set of different countries. In this specification, there is evidence that such a remedy is more likely to be challenged at the WTO. This could be indicative of the foreign country seeking to increase market access while its primary competitors would still be constrained by other U.S.-imposed remedies. If it were successful, the country would essentially receive preferential access to the U.S. market. Nevertheless, we also note that inclusion of this variable does not substantively affect the qualitative pattern of results regarding the other variables of interest to the estimation.

\footnotetext{
${ }^{29}$ In future research, as more data becomes available, it would also be useful to estimate a model with country fixed effects and which also investigates dynamic questions such as when (e.g., how long after imposition) trade remedies get challenged, etc.

${ }^{30}$ On the other hand, to the extent that a U.S. trade remedy investigation leads to differential duties imposed on firms from different EU member states (implicitly providing firms from some EU states preferential access to the U.S. market relative to other EU competitors, this could make it more difficult for the EU to act jointly.
} 


\section{Conclusion}

Regardless of whether or not the WTO's dispute settlement process and institutional framework was designed to handle substantial litigation over nationally-imposed trade remedies, it currently finds disputes over trade remedies as a central topic of concern. Without substantial institutional reform or changes in government attitudes, one implication of the current global trend in administered use of contingent trade policy protection is that how the DSU resolves conflicts over antidumping, countervailing duties and safeguards will be an important factor in determining at least the perception of the WTO's broader record of success in the multilateral trading system. A large and increasing share of the recent dispute settlement caseload involves challenges to nationally imposed trade remedies over imports, and in particular the United States' imposition of trade remedies.

We have provided evidence that some of the standard economic determinants affect the litigation decision to file a dispute against U.S.-imposed remedies: the size of imports lost to the trade remedy, the foreign country's capacity to retaliate, and the size of the trade remedy that was imposed. Nevertheless, we document two additional results in particular that are a source of potential concern. First, the evidence implies that an adversely affected foreign industry may resort to a reciprocal (and retaliatory) antidumping measure against the protected U.S. industry if it has the capacity to do so, in lieu of working to convince its government to file a dispute at the WTO on its behalf that would seek the removal of the U.S. trade remedy measure. Second, there is also evidence that less diversified foreign exporters are less likely to challenge U.S. trade remedies, which is a concern if these exporters are systematically less likely to be able to "deflect" their lost exports to third markets when a trade remedy shuts them out of the U.S.

We do note that there are a number of caveats to our approach, as well as a number of unanswered questions that could be an area of future research. First, our analysis focuses on U.S. trade remedies only. While this is a logical place to commence an empirical investigation into the questions raised here, it would be useful to know the usefulness of the lessons learned from the experience of challenging U.S. remedies for other remedy-imposing countries. Second, our approach also does not allow us to investigate a second important question: Why does the United States challenge so few of the foreign-imposed trade remedies targeting U.S. exporters, especially given the evidence that its exporters are the third most targeted set of producers in worldwide antidumping? Third, while we have sought to carefully characterize important elements of the data, our econometric results are based on a relatively small number of pooled observations, whose lack of independence may generate additional statistical 
concerns. Nevertheless, this approach is merely a starting point, and our results do illustrate some interesting patterns in the underlying data which should be the focus of additional future research. 


\section{References}

Bagwell, Kyle and Robert W. Staiger (2002). The Economics of the World Trading System Cambridge, MA: MIT Press.

Bagwell, Kyle and Robert W. Staiger (2004). "Enforcement, Private Political Pressure and the GATT/WTO Escape Clause." University of Wisconsin manuscript [available at http://www.ssc.wisc.edu/ rstaiger/ ], December.

Blonigen,, Bruce A. and Chad P. Bown (2003). “Antidumping and Retaliation Threats," Journal of International Economics 60(2): 249-273.

Blonigen, Bruce A. and Thomas J. Prusa (2003). "Antidumping," in E. Kwan Choi and James Harrigan (eds.) Handbook of International Trade Oxford, UK: Blackwell Publishers.

Bown, Chad P. (2002). "Why Are Safeguards Under the WTO So Unpopular?" World Trade Review 1(1): 47-62.

Bown, Chad P. (2004a). "On the Economic Success of GATT/WTO Dispute Settlement," The Review of Economics and Statistics 86(3): 811-823.

Bown, Chad P. (2004b). "Participation in WTO Dispute Settlement: Complainants, Interested Parties and Free Riders," Brandeis University manuscript [available at http://www.brandeis.edu cbown/ ], August (revised).

Bown, Chad P. (2004c). "How Different are Safeguards from Antidumping: Evidence from U.S. Trade Policies Toward Steel," Brandeis University manuscript [available at http://www.brandeis.edu c cbown/ ], July.

Bown, Chad P., Bernard Hoekman and Çaglar Ozden (2003). "The Pattern of U.S. Antidumping: The Path from Initial Filing to WTO Dispute Settlement," World Trade Review 2(3): 349-371.

Bown, Chad P. and Meredith A. Crowley (2004). “Trade Deflection and Trade Depression," Federal Reserve Bank of Chicago Working Paper 2003-26, February.

Busch, Marc L. and Eric Reinhardt (2000). "Bargaining in the Shadow of the Law: Early Settlement in GATT/WTO Disputes," Fordham International Law Journal 24(1): 158-172.

Cunningham, Richard O. and Troy H. Crib (2003). "Dispute Settlement Through the Lens of 'Free Flow of Trade' A Review of WTO Dispute Settlement of U.S. Anti-Dumping and Countervailing Duty Measures" Journal of International Economic Law 6(1): 155-170.

Durling, James P. (2003). "Deference, But Only When Due: WTO Review of Anti-Dumping Measures,” Journal of International Economic Law 6(1): 125-153.

Feenstra, Robert C., John Romalis and Peter K. Schott (2002). "U.S. Imports, Exports and Tariff Data, 1989 to 2001.” NBER Working Paper No. 9387, November.

Feinberg, Robert M. and Kara M. Olson (2004). "The Spread of Antidumping Regimes and the Role of Retaliation in Filings.” American University manuscript [available at http://nw08.american.edu/ olson/research.htm ], November.

Greene, William H. (2000). Econometric Analysis (4 $4^{\text {th }}$ edition) New Jersey: Prentice Hall.

Greenwald, John (2003). “WTO Dispute Settlement: An Exercise in Trade Law Legislation?” Journal of International Economic Law 6(1): 113-124.

Hansen, Wendy and Thomas J. Prusa (1996). "Cumulation and ITC Decision-Making: The Sum of the Parts is Greater Than the Whole," Economic Inquiry 34: 746-69. 
Hansen, Wendy and Thomas J. Prusa (1997). "The Economics and Politics of Trade Policy: An Empirical Analysis of ITC Decision Making," Review of International Economics 5: 230-245

Heckman, James J. (1979). “Sample Selection Bias as a Specification Error,” Econometrica 47: 153-161.

Hoekman, Bernard M. and Michael M. Kostecki (2001). The Political Economy of the World Trading System: The WTO and Beyond ( $2^{\text {nd }}$ edition) New York: Oxford University Press.

Holmes, Peter, Jim Rollo and Alasdair Young (2003). "Emerging Trends in WTO Dispute Settlement: Back to GATT?" University of Sussex, manuscript.

Horn, Henrik, Petros C. Mavroidis and Håkan Nordström (1999). "Is the Use of the WTO Dispute Settlement System Biased?" CEPR Discussion Paper No. 2340, December.

Irwin, Douglas A. (2003). "Causing Problems? The WTO Review of Causation and Injury Attribution in U.S. Section 201 Cases," World Trade Review 2(3): 297-325.

Martin, Alberto, and Wouter Vergote. (2004) “Antidumping: Welfare Enhancing Retaliation?” Unpublished manuscript, Columbia University, October.

Prusa, Thomas J. (1992). "Why Are So Many Antidumping Petitions Withdrawn?" Journal of International Economics 33(1/2): 1-20.

Prusa, Thomas J. (2001). “On the Spread and Impact of Antidumping," Canadian Journal of Economics 34(3): 591611.

Prusa, Thomas J. and Susan Skeath (forthcoming). “Modern Commercial Policy: Managed Trade or Retaliation?” in James Hartigan (ed.), Handbook of International Trade and Law (Malden, MA, Blackwell Publishing).

Staiger, Robert W. And Frank A. Wolak (1994). "Measuring Industry-Specific Protection: Antidumping in the United States," Brookings Papers on Economic Activity: Microeconomics 51-118.

Sykes, Alan O. (1991). "Protectionism as a 'Safeguard': A Positive Analysis of the GATT 'Escape Clause' with Normative Speculations," University of Chicago Law Review 58: 255-305.

Sykes, Alan O. (2003). “The Safeguards Mess: A Critique of WTO Jurisprudence,” World Trade Review 2(3): 261295.

Tarullo, Daniel K. (2003). "Paved with Good Intentions: The Dynamic Effects of WTO Review of Anti-Dumping Action," World Trade Review 2(3): 373-393.

Van de Ven, Wynand and Bernard Van Praag (1981). "The Demand for Deductibles in Private Health Insurance: A Probit Model with Sample Selection," Journal of Econometrics 17: 229-252.

WTO (2004). "WTO Dispute Settlement: Status in Brief of the Disputes," WTO website available at http://www.wto.org/english/tratop_e/dispu_e/dispu_status_e.htm, last accessed 30 September.

Zanaradi, Maurizio (2004). "Antidumping: What are the Numbers to Discuss at Doha?" The World Economy 27(3): 403-433. 
Table 1. WTO Trade Disputes, 1995-2004

\begin{tabular}{lcc}
\hline Respondent Trade Policy under Dispute & $\begin{array}{c}\text { Disputes Initiated } \\
\text { Between } 1995 \text { and } 1998\end{array}$ & $\begin{array}{c}\text { Disputes Initiated } \\
\text { Between } 1999 \text { and 2004 }\end{array}$ \\
\hline
\end{tabular}

Antidumping law, practice or measure*

13

41

Countervailing duty law, practice or measure

4

10

Other trade remedy law, practice or measure (e.g., safeguards)

4

27

Total trade remedy disputes

21

78

Other non-trade remedy disputes

133

89

Total disputes (321)

154

167

\footnotetext{
Note: ${ }^{\dagger}$ disputes initiated through 15 November 2004. *For a dispute challenging more than one type of trade remedy (e.g., both an imposed antidumping measure and a countervailing duty), we avoid double-counting by entering it as challenging one type of trade remedy only (typically, an antidumping measure).
} 
Table 2. GATT/WTO Dispute Settlement Proceedings against United States Antidumping, Countervailing Duty and Safeguard Trade Remedy Actions, * 1992-2003

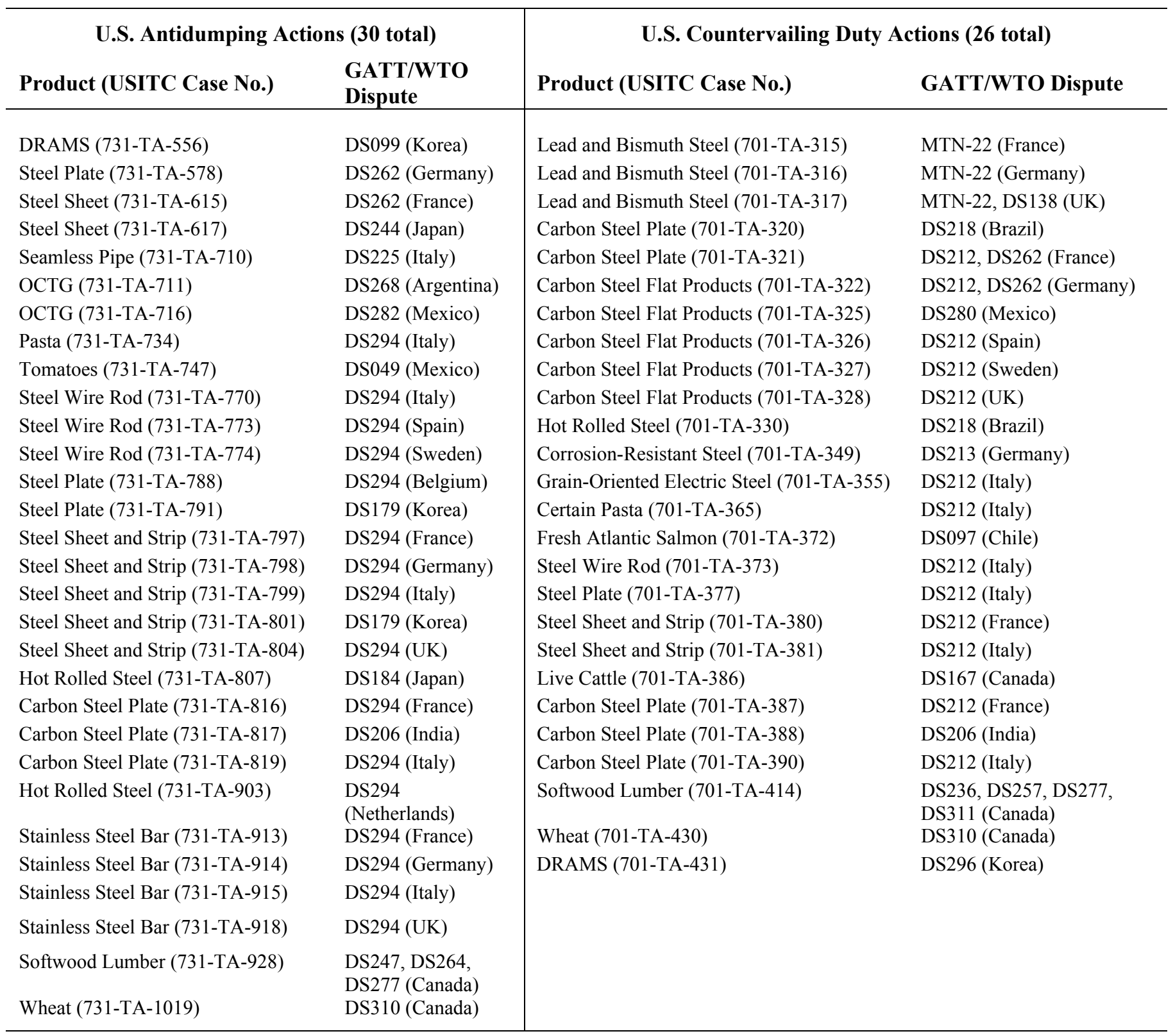

\section{U.S. Safeguard Actions (6 total)}

Product (USITC Case No.) GATT/WTO Dispute

Broom Corn Brooms (TA-201-65)

Wheat Gluten (TA-201-67)

Lamb Meat (TA-201-68)

Steel Wire Rod (TA-201-69)

Circular Welded Pipe (TA-201-70)

Certain Steel Products (TA-201-73)
DS078 (Colombia)

DS166 (EU)

DS177 (Australia), DS178 (New Zealand)

DS214 (EU)

DS202 (Korea), DS214 (EU)

DS248 (EU), DS249 (Japan), DS251 (Korea), DS252 (China), DS253 (Switzerland), DS254 (Norway), DS258 (New Zealand), DS259 (Brazil), DS274 (Taiwan)

Note: *not including U.S. use of special safeguard actions on apparel, textiles and clothing, China, or agriculture. 
Table 3. U.S. Trade Remedy Investigations, Actions, and GATT/WTO Challenges, by Member,* 1992-2003

\begin{tabular}{|c|c|c|c|c|c|c|}
\hline \multirow[b]{2}{*}{ Country } & \multicolumn{3}{|c|}{ Antidumping } & \multicolumn{3}{|c|}{ Countervailing Duties } \\
\hline & Investigations & $\begin{array}{c}\text { Resulting in } \\
\text { Remedies }\end{array}$ & $\begin{array}{c}\text { Challenged } \\
\text { at WTO }\end{array}$ & Investigations & $\begin{array}{c}\text { Resulting in } \\
\text { Remedies }\end{array}$ & $\begin{array}{c}\text { Challenged } \\
\text { at WTO }\end{array}$ \\
\hline Japan & 42 & 24 & 2 & 0 & 0 & 0 \\
\hline Korea & 35 & 17 & 3 & 10 & 6 & 1 \\
\hline China & 24 & 15 & 0 & 0 & 0 & 0 \\
\hline India & 22 & 10 & 1 & 10 & 5 & 1 \\
\hline Mexico & 22 & 9 & 2 & 4 & 1 & 1 \\
\hline Germany & 22 & 8 & 3 & 9 & 5 & 3 \\
\hline Canada & 21 & 5 & 1 & 11 & 3 & 2 \\
\hline Brazil & 20 & 10 & 0 & 10 & 4 & 1 \\
\hline Italy & 18 & 10 & 6 & 12 & 9 & 6 \\
\hline France & 16 & 8 & 4 & 9 & 5 & 3 \\
\hline South Africa & 16 & 6 & 0 & 2 & 2 & 0 \\
\hline Venezuela & 14 & 4 & 0 & 4 & 0 & 0 \\
\hline United Kingdom & 13 & 4 & 2 & 4 & 3 & 2 \\
\hline Indonesia & 12 & 6 & 0 & 4 & 2 & 0 \\
\hline Thailand & 12 & 5 & 0 & 2 & 1 & 0 \\
\hline Spain & 11 & 4 & 1 & 2 & 1 & 1 \\
\hline Argentina & 8 & 4 & 1 & 3 & 2 & 0 \\
\hline Belgium & 8 & 2 & 1 & 4 & 2 & 0 \\
\hline Netherlands & 7 & 4 & 1 & 1 & 1 & 0 \\
\hline Malaysia & 7 & 2 & 0 & 0 & 0 & 0 \\
\hline Romania & 6 & 3 & 0 & 0 & 0 & 0 \\
\hline Turkey & 6 & 2 & 0 & 2 & 1 & 0 \\
\hline Australia & 6 & 1 & 0 & 0 & 0 & 0 \\
\hline Austria & 5 & 0 & 0 & 3 & 0 & 0 \\
\hline Chile & 4 & 3 & 0 & 2 & 0 & 0 \\
\hline Portugal & 4 & 1 & 0 & 0 & 0 & 0 \\
\hline Israel & 4 & 0 & 0 & 2 & 0 & 0 \\
\hline Sweden & 3 & 2 & 1 & 2 & 1 & 1 \\
\hline Trinidad and Tobago & 3 & 1 & 0 & 2 & 0 & 0 \\
\hline Costa Rica & 3 & 0 & 0 & 0 & 0 & 0 \\
\hline Poland & 2 & 2 & 0 & 0 & 0 & 0 \\
\hline Hungary & 2 & 1 & 0 & 1 & 1 & 0 \\
\hline Czech Republic & 2 & 1 & 0 & 0 & 0 & 0 \\
\hline New Zealand & 2 & 0 & 0 & 3 & 0 & 0 \\
\hline Colombia & 2 & 0 & 0 & 0 & 0 & 0 \\
\hline Egypt & 2 & 0 & 0 & 0 & 0 & 0 \\
\hline Finland & 1 & 1 & 0 & 0 & 0 & 0 \\
\hline Latvia & 1 & 1 & 0 & 0 & 0 & 0 \\
\hline Moldova & 1 & 1 & 0 & 0 & 0 & 0 \\
\hline Philippines & 1 & 1 & 0 & 0 & 0 & 0 \\
\hline Denmark & 1 & 0 & 0 & 1 & 0 & 0 \\
\hline Greece & 1 & 0 & 0 & 0 & 0 & 0 \\
\hline Hong Kong & 1 & 0 & 0 & 0 & 0 & 0 \\
\hline Ireland & 1 & 0 & 0 & 0 & 0 & 0 \\
\hline Lithuania & 1 & 0 & 0 & 0 & 0 & 0 \\
\hline Singapore & 1 & 0 & 0 & 0 & 0 & 0 \\
\hline Slovak Republic & 1 & 0 & 0 & 0 & 0 & 0 \\
\hline Total & 417 & 178 & 29 & 119 & 55 & 22 \\
\hline
\end{tabular}

Note: *since the country's date (year) of GATT/WTO membership. The 51 WTO challenges in this data set are less than the 56 antidumping and countervailing duty challenges listed in table 2 because 5 WTO challenges listed in table 2 were to investigations that did not result in the imposition of remedies. 
Table 4. Characteristics of U.S. Trade Remedies against GATT/WTO Members that Face Trade Disputes Versus Those That Do Not, 1992-2003

Challenged with a GATT/WTO Dispute
Not Challenged with a GATT/WTO Dispute
Value* of Lost Exports

(mean difference between targeted exports in $t+1$ versus $t-1$ )

Foreign Retaliation Capacity through GATT/WTO

(mean share of total U.S. exports to the world sent to targeted country)

Level of U.S.-Imposed Trade Remedy

(mean duty)

Foreign Retaliation Capacity through Reciprocal Antidumping (mean share of remedy-protected U.S. industry-level production that is exported to targeted country)

Diversity of Foreign Exports of Targeted Product (mean share of foreign total exports of remedy-targeted products sent to rest of the world)
-\$49.9 million

$-\$ 3.2$ million

$16.9 \%$

$6.5 \%$

$14.7 \%$

$45.1 \%$

$0.7 \%$

$0.9 \%$

$63.0 \%$

$45.0 \%$

Note: Time $t$ is the year of the initiation of the trade remedy investigation. ${ }^{*}$ Constant (2000) dollars. 
Table 5. Summary Statistics for Variables Used in the Baseline Econometric Investigation

\begin{tabular}{|c|c|c|c|c|c|}
\hline Variables & $\begin{array}{l}\text { Predicted } \\
\text { Sign }\end{array}$ & Mean & $\begin{array}{l}\text { Standard } \\
\text { Deviation }\end{array}$ & Minimum & Maximum \\
\hline \multicolumn{6}{|l|}{$\underline{\text { Selection Equation }}$} \\
\hline \multicolumn{6}{|l|}{ Dependent Variable } \\
\hline $\begin{array}{l}\text { Indicator equal to } 1 \text { if the GATT/WTO member under } \\
\text { investigation faced an affirmative U.S. trade remedy } \\
\text { ruling } \\
\text { Explanatory Variables }\end{array}$ & & 0.399 & 0.490 & 0 & 1 \\
\hline Import penetration ratio in $t-1$ & {$[+]$} & 0.019 & 0.038 & 0 & 0.361 \\
\hline Percent change in product-level imports between $t-2$ and $t-1$ & {$[+]$} & 0.271 & 0.686 & -1.998 & 1.998 \\
\hline Level $^{\dagger}$ of industry employment in $t-1$ & {$[+]$} & 1.000 & 0.696 & 0.027 & 5.009 \\
\hline Percent change in industry employment between $t-2$ and $t-1$ & {$[-]$} & -0.026 & 0.054 & -0.409 & 0.265 \\
\hline $\begin{array}{l}\text { Percent change in capacity utilization rate between } t-2 \text { and } \\
t-1\end{array}$ & {$[-]$} & -0.016 & 0.106 & -0.346 & 0.223 \\
\hline Concentration ratio ${ }^{\dagger}$ in $t-1$ & {$[+]$} & 0.351 & 0.125 & 0.05 & 0.807 \\
\hline Share of U.S. total exports sent to the foreign country in $t-1$ & {$[-]$} & 0.092 & 0.094 & 0.000 & 0.256 \\
\hline $\begin{array}{l}\text { Indicator that the investigation involved the U.S. steel } \\
\text { industry }\end{array}$ & {$[+]$} & 0.580 & 0.494 & 0 & 1 \\
\hline
\end{tabular}

\section{$\underline{\text { Regression Equation }}$}

\section{Dependent Variable}

Indicator equal to 1 if U.S. trade remedy faced a

GATT/WTO trade dispute

0.381

0

1

Explanatory Variables

Log of value of targeted product imports in $t-1$

\begin{tabular}{ccccc}
{$[+]$} & 16.857 & 1.747 & 9.431 & 23.141 \\
{$[-]$} & 0.496 & 0.254 & 0.005 & 0.967 \\
{$[? ?]$} & 0.456 & 0.521 & 0 & 3.290 \\
{$[+]$} & 0.080 & 0.084 & 0 & 0.240 \\
{$[-]$} & 0.008 & 0.016 & 0 & 0.095 \\
{$[+]$} & 12.962 & 6.209 & 0 & 23 \\
{$[-]$} & 8.801 & 1.497 & 5.833 & 10.715 \\
\hline
\end{tabular}

Notes: Time $t$ is the year of the initiation of the trade remedy investigation. ${ }^{\dagger}$ indicates the underlying variable was scaled by 100 . 


\section{Table 6a. Estimated Marginal Effects of the U.S. Decision of Whether to Impose a Trade Remedy against an Investigated GATT/WTO Member, 1992-2003 \\ (First Stage of Probit Model with Selection)}

\begin{tabular}{|c|c|c|c|}
\hline \multirow[b]{2}{*}{ Explanatory Variables } & \multicolumn{3}{|c|}{$\begin{array}{c}\text { Dependent variable }=1 \\
\text { if investigated GATT/WTO member faced U.S. remedy }\end{array}$} \\
\hline & $\begin{array}{c}\text { Baseline } \\
\text { (AD cases only) } \\
\text { (1) }\end{array}$ & $\begin{array}{l}\text { AD and CVD } \\
\text { cases } \\
(2)\end{array}$ & $\begin{array}{l}\text { Include injury } \\
\text { in second stage } \\
\text { (3) }\end{array}$ \\
\hline Import penetration ratio in $t-1$ & $\begin{array}{l}2.729^{\mathrm{a}} \\
(0.770)\end{array}$ & $\begin{array}{l}2.365^{\mathrm{a}} \\
(0.803)\end{array}$ & $\begin{array}{l}2.716^{\mathrm{a}} \\
(0.774)\end{array}$ \\
\hline $\begin{array}{l}\text { Percent change in product-level imports between } t-2 \\
\quad \text { and } t-1\end{array}$ & $\begin{array}{c}0.069 \\
(0.051)\end{array}$ & $\begin{array}{l}0.107^{\text {a }} \\
(0.040)\end{array}$ & $\begin{array}{c}0.070 \\
(0.048)\end{array}$ \\
\hline Level of industry employment in $t-1$ & $\begin{array}{c}0.001 \\
(0.064)\end{array}$ & $\begin{array}{l}-0.041 \\
(0.065)\end{array}$ & $\begin{array}{c}0.004 \\
(0.065)\end{array}$ \\
\hline $\begin{array}{l}\text { Percent change in industry employment between } t-2 \\
\quad \text { and } t-1\end{array}$ & $\begin{array}{c}0.098 \\
(0.756)\end{array}$ & $\begin{array}{c}0.425 \\
(0.721)\end{array}$ & $\begin{array}{c}0.072 \\
(0.776)\end{array}$ \\
\hline $\begin{array}{l}\text { Percent change in capacity utilization rate between } t \text { - } \\
2 \text { and } t-1\end{array}$ & $\begin{array}{c}0.018 \\
(0.582)\end{array}$ & $\begin{array}{c}0.017 \\
(0.460)\end{array}$ & $\begin{array}{c}0.043 \\
(0.569)\end{array}$ \\
\hline Concentration ratio in $t-1$ & $\begin{array}{c}0.118 \\
(0.338)\end{array}$ & $\begin{array}{c}0.114 \\
(0.293)\end{array}$ & $\begin{array}{c}0.115 \\
(0.335)\end{array}$ \\
\hline $\begin{array}{l}\text { Share of U.S. total exports sent to the foreign country } \\
\text { in } t-1\end{array}$ & $\begin{array}{l}-0.720^{b} \\
(0.344)\end{array}$ & $\begin{array}{l}-0.496 \\
(0.305)\end{array}$ & $\begin{array}{l}-0.732^{b} \\
(0.349)\end{array}$ \\
\hline $\begin{array}{l}\text { Indicator that the investigation involved the U.S. steel } \\
\text { industry }\end{array}$ & $\begin{array}{c}0.077 \\
(0.122)\end{array}$ & $\begin{array}{c}0.074 \\
(0.103)\end{array}$ & $\begin{array}{c}0.084 \\
(0.126)\end{array}$ \\
\hline Observations in probit selection equation & 331 & 413 & 331 \\
\hline Log-likelihood & -241.25 & -303.78 & -240.24 \\
\hline
\end{tabular}

Notes: In parentheses are White's heteroskedasticity-consistent standard errors corrected for clustering on related AD/CVD cases, with ${ }^{\mathrm{a}, \mathrm{b}}$, and ${ }^{\mathrm{c}}$ denoting variables statistically different from zero at the 1,5 and 10 percent levels, respectively. Time $t$ is the year of the initiation of the trade remedy investigation. Each stage also estimated with a constant term whose estimates are suppressed. 


\section{Table 6b. Estimated Marginal Effects of an Affected Exporting Countries' Decision to File a GATT/WTO Trade Dispute Against a U.S.-Imposed Trade Remedy, 1992-2003 \\ (Second Stage of Probit Model with Selection)}

\section{Probit Regression Equation:}

Dependent variable $=1$

if U.S.-imposed remedy faced initiation of GATT/WTO dispute

\section{Explanatory Variables}

\section{Size of Market Access Benefits}

Log of value of targeted product imports in $t-1$

Share of foreign total exports of remedy-targeted products sent to rest of the world in $t-1$

Level of U.S.-imposed trade remedy

Baseline
(AD cases only)
(1)

$0.056^{\mathrm{a}}$

(0.017)

$0.397^{\mathrm{b}}$

(0.172)

$-0.508^{\mathrm{c}}$

(0.294)

$1.676^{\mathrm{b}}$

(0.706)
AD and CVD
cases

(2)
Include injury
in second stage
(3)

$0.070^{\mathrm{a}}$
$(0.016)$

$0.239^{\mathrm{c}}$

(0.142)

$-0.337$

(0.217)

$1.140^{\mathrm{b}}$

(0.574)

$1.743^{\mathrm{b}}$

(0.690)

$0.052^{\mathrm{a}}$
$(0.018)$

$0.431^{\mathrm{b}}$

(0.190)

$-0.516^{\mathrm{c}}$

(0.293)

No selection

equation

(4) country in $t-1$

Percent change in product-level imports between $t-2$ and $t-1$

Percent change in capacity utilization rate between $t-2$ and $t-1$

\section{Alternative Retaliation Instrument}

Share of value of U.S. industry level production exported to the foreign country in $t-1$

$-7.129^{a}$

(2.104)

$-5.566^{\mathrm{a}}$

(1.838)

$-6.989^{a}$

(2.087)

$-0.028$

(0.077)

$-0.477$

(0.288)

\section{Capacity to Absorb Litigation Costs}

Delegates at the WTO Secretariat

$-0.009$

(0.006)

$-0.007$

$(0.005)$

$-0.009$

$(0.007)$

$-0.009$

$-0.050$

$-0.024$

(0.028)

$-0.056$

$(0.040)$

$-0.050$

$(0.040)$ $0.059^{\mathrm{a}}$

(0.016)

$0.392^{b}$

$-0.507^{\mathrm{c}}$

(0.299)

$1.689^{b}$

(0.717)

$$
-
$$

\begin{tabular}{lcccc}
\hline Observations in probit regression equation & 132 & 164 & 132 & 132 \\
Log-likelihood & -241.25 & -303.78 & -240.24 & -28.97 \\
\hline \hline
\end{tabular}

Notes: In parentheses are White's heteroskedasticity-consistent standard errors corrected for clustering on related AD/CVD cases, with ${ }^{\mathrm{a}, \mathrm{b}}$, and ${ }^{\mathrm{c}} \mathrm{denoting}^{\mathrm{s}}$ variables statistically different from zero at the 1,5 and 10 percent levels, respectively. Time $t$ is the year of the initiation of the trade remedy investigation. Each stage also estimated with a constant term whose estimates are suppressed. 


\section{Probit Regression Equation:}

Dependent variable $=1$

if U.S.-imposed remedy faced initiation of GATT/WTO dispute

Explanatory Variables

\section{Alternative \\ export \\ deflection/ \\ diversity \\ variable}

(5)

\section{Size of Market Access Benefits}

Log of value of targeted product imports in $t-1$

Share of foreign total exports of remedy-targeted products sent to rest of the world in $t-1$

Growth rate of foreign total exports of remedytargeted products to rest of the world between $t-1$ and $t+1$

Level of U.S.-imposed trade remedy

\section{Probability of Realizing Benefits}

Share of U.S. total exports sent to the foreign country

\section{Alternative Retaliation Instrument}

Share of U.S. industry level production exported to the foreign country

\section{Capacity to Absorb Litigation Costs}

Delegates at the WTO Secretariat

Log of level of per capita GDP of foreign country

\section{Political Costs}

Share of total foreign aid deriving from the U.S.

\section{Other Variables}

Indicator that targeted country was a member of the EU

Indicator that $\mathrm{AD} / \mathrm{CVD}$ was one of multiple trade remedies simultaneously imposed on the same product

$\begin{array}{cccc}0.046^{\mathrm{c}} & 0.040 & 0.054^{\mathrm{a}} & 0.057^{\mathrm{b}} \\ (0.028) & (0.026) & (0.023) & (0.023) \\ -- & -- & 0.430^{\mathrm{b}} & 0.334^{\mathrm{b}} \\ & & (0.199) & (0.159) \\ 0.100 & - & -- & -- \\ (0.064) & & & \\ -0.662^{\mathrm{b}} & -0.514^{\mathrm{c}} & -0.525^{\mathrm{c}} & -0.376 \\ (0.331) & (0.247) & (0.304) & (0.259) \\ & & & \\ 1.353^{\mathrm{b}} & 0.961^{\mathrm{b}} & 2.353^{\mathrm{c}} & 1.411^{\mathrm{b}} \\ (0.579) & (0.485) & (1.260) & (0.624) \\ & & & \\ -8.739^{\mathrm{a}} & -6.766^{\mathrm{a}} & -7.724^{\mathrm{a}} & -5.465^{\mathrm{a}} \\ (2.654) & (2.236) & (2.458) & (2.083) \\ & & & \\ -0.008 & -0.009 & -0.011 & -0.007 \\ (0.007) & (0.006) & (0.008) & (0.005) \\ 0.007 & 0.011 & -0.053 & -0.050 \\ (0.047) & (0.036) & (0.042) & (0.034)\end{array}$

$0.057^{\mathrm{b}}$

$(0.023)$

$(0.042)$

$(0.034)$

$(0.256)$

Add E.U. Dummy

(7)

\section{Add dummy for one of multiple}

AD/CVD remedies

(8)

\begin{tabular}{lcccc}
\hline Observations in probit regression equation & 149 & 132 & 132 & 132 \\
Log-likelihood & -272.44 & -288.13 & -241.06 & -239.33 \\
\hline \hline
\end{tabular}

Notes: *Estimates of the Heckman selection equation are omitted, but are available from the author upon request. In parentheses are White's heteroskedasticityconsistent standard errors corrected for clustering on related $\mathrm{AD} / \mathrm{CVD}$ cases, with ${ }^{\mathrm{a}, \mathrm{b}}$, and ${ }^{\mathrm{c}}$ denoting variables statistically different from zero at the 1,5 and 10 percent levels, respectively. Time $t$ is the year of the initiation of the trade remedy investigation. Each stage also estimated with a constant term whose estimates are suppressed. 